\title{
The Pharmacist Role in Predicting and Improving Medication Adherence in Heart Failure Patients
}

\author{
Estella M. Davis, PharmD, BCPS; Kathleen A. Packard, PharmD, BCPS (AQ Cardiology); \\ and Cynthia A. Jackevicius, BScPhm, PharmD, MSc, FCSHP, BCPS (AQ Cardiology), FAHA
}

\begin{abstract}
BACKGROUND: Heart failure is one of the most common reasons for hospital admissions in patients aged 65 years and older, with an estimated 1 million hospitalizations annually. In 2010, health care expenditures for heart failure were estimated to be $\$ 32$ billion. Nonadherence to medications and lifestyle contributes to hospital admissions in up to one-third of patients. Efforts to reduce readmissions are of critical importance. Pharmacist involvement in the management of heart failure patients has been shown to reduce heart failure hospitalizations, with trends towards a reduction in mortality. Literature is scarce on instruments that clinicians can use to identify patients at risk for medication nonadherence.
\end{abstract}

OBJECTIVES: To (a) describe factors that predict medication adherence for patients with heart failure, (b) evaluate the impact and value of pharmacist interventions on adherence and outcomes, and (c) assess tools to predict medication nonadherence in heart failure patients.

METHODS: From inception to September 2013, a search was conducted in the databases MEDLINE, PubMed, CINAHL, and The Cochrane Library to identify relevant studies for 3 separate searches, identifying predictors of medication adherence in heart failure patients, pharmacist involvement to impact medication adherence, and tools to predict medication nonadherence in this population.

RESULTS: Many significant predictors of both medication adherence and nonadherence have been identified in heart failure patients. Studies evaluating the effect of pharmacist involvement in the management of heart failure demonstrated improvements in medication adherence that dissipated once the intervention was withdrawn. The Morisky Medication Adherence Scale and the Merck Adherence Estimator are simple and practical tools that may be useful for identifying nonadherence in heart failure patients.

CONCLUSIONS: Clinicians should be cognizant of factors that may affect medication adherence in heart failure patients and be aware of instruments available to predict the risk for medication nonadherence. Pharmacist interventions should be part of a multidisciplinary system of care initiated at discharge that involve personal contact and are continued indefinitely in order to sustain these benefits.

J Manag Care Pharm. 2014;20(7):741-55

Copyright $\odot 2014$, Academy of Managed Care Pharmacy. All rights reserved.

\section{What is already known about this subject}

Heart failure is one of the most common reasons for readmissions in the elderly, with readmission rates as high as $44 \%$ within the first 6 months and more than two-thirds within the first 12 months.

Rates of medication nonadherence in these patients are reported to be between $40 \%-60 \%$, and nonadherence to medications and lifestyle contributes to hospital admissions in up to one-third of patients.
Pharmacist involvement in the management of heart failure patients has been shown to reduce heart failure hospitalizations with trends towards a reduction in mortality; however, few validated screening tools exist to help clinicians identify patients at risk for adherence to their medications.

\section{What this study adds}

This literature evaluation identified many significant predictors of both medication adherence and nonadherence in heart failure patients. These predictors are summarized according to the World Health Organization adherence model.

The assessment of studies evaluating pharmacist involvement in the treatment of heart failure demonstrated that the improvement in medication adherence lacked durability once the intervention ceased.

The literature evaluation supports pharmacist interventions as part of a multidisciplinary system of care initiated at discharge that involves personal contact continued indefinitely to sustain adherence and that the Morisky Medication Adherence Scale and Merck Adherence Estimator are tools that may be useful to identifying nonadherence in heart failure patients.

$\mathrm{H}$ eart failure (HF) is one of the most common reasons for hospital admissions in patients aged 65 years and older, with an estimated 1 million hospitalizations annually. ${ }^{1}$ The costs are also staggering and were estimated to be $\$ 32$ bil-

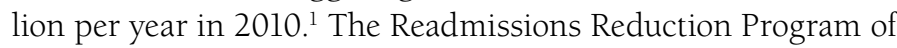
the Affordable Care Act currently calls for a 1\%-2\% reduction in hospital reimbursement for Medicare patients with HF, depending on readmission ratios. ${ }^{2}$ Because $\mathrm{HF}$ readmissions have been reported to be as high has 44\% within the first 6 months and more than two-thirds within the first 12 months, efforts to reduce readmissions are of critical importance. ${ }^{3,4}$

Nonadherence to either medications or lifestyle modifications is a major cause for readmission and has been found to contribute to hospital admissions in up to one-third of patients. ${ }^{5,6}$ Rates of medication nonadherence in HF patients have varied widely, with most rates between 40\%-60\%. Nonadherence to HF medication has also been associated with an increase in cardiac-related events, including emergency department (ED) visits and hospitalizations, an increase in health care costs, and 
a reduction in quality of life. ${ }^{8-14}$ Furthermore, the Candesartan in Heart Failure Assessment of Reduction in Mortality and Morbidity (CHARM) study demonstrated that increased adherence to HF medications was associated with a $35 \%$ reduction in mortality (hazard ratio $[\mathrm{HR}]=0.65,95 \%$ confidence interval $[\mathrm{CI}]=0.57-0.75, P<0.0001) .{ }^{15}$

Efforts to reduce HF readmissions are of critical importance. Interventions to identify, predict, and reduce nonadherence have the potential to improve clinical outcomes in HF patients. Pharmacists are well suited to optimize drug therapy regimens, identify barriers to medication adherence, and develop ways to address, as well as educate, patients and the health care team about medication-related topics. ${ }^{16}$ Pharmacist involvement in the management of these patients has been shown to reduce HF hospitalizations, with trends towards a reduction in mortality. ${ }^{17}$ Literature is scarce on instruments that clinicians can use to identify patients at risk for medication nonadherence. The objective of this review was to (a) describe factors that predict medication adherence for patients with HF, (b) evaluate the impact and value of pharmacist interventions on adherence and outcomes, and (c) assess tools to predict medication nonadherence in HF patients.

\section{Methods}

\section{Literature Search}

The elements of this subject review of medication adherence in HF patients included a series of electronic literature searches to identify (a) studies relative to identifying predictors of medication adherence in HF patients, (b) pharmacist involvement to impact medication adherence, and (c) tools to predict medication nonadherence in this population. The studies were published in English but not exclusive by country of origin. From inception to September 2013, a search was conducted in MEDLINE, PubMed, CINAHL (Cumulative Index to Nursing and Allied Health Literature), and The Cochrane Library to identify relevant studies for all 3 elements of this review. Reference lists of relevant articles were also examined by investigators to identify further studies for inclusion.

The literature search identifying studies characterizing predictors of medication adherence in HF patients was conducted using the common key words "predictor," "medication," "adherence," "nonadherence," "compliance," "noncompliance," and "heart failure." Studies were narrowed further to include only those describing use of multivariate regression analysis in study methods to determine significant predictors of medication adherence to HF medications.

The pharmacist intervention literature search was conducted using the common key words "pharmacist," "heart failure," "pharmacy," "multidisciplinary," and "interdisciplinary" to evaluate any pharmacist intervention in the treatment of HF patients. All studies that captured medication adherence were included. The review also included studies that did not measure medication adherence, but which measured mortality or hospital admission/readmission outcomes.
The literature search to evaluate tools to predict medication nonadherence was conducted using the common key words "medication," "adherence," "nonadherence," "compliance," "predictor," "survey," "questionnaire," "tool," "scale," and "screening." Studies were included for those instruments assessed in disease states other than HF due to a paucity of available tools validated exclusively in this population.

Descriptive analysis was performed for the included studies in this review.

\section{Results}

\section{Predictors of Medication Adherence in Heart Failure}

Medication adherence has been defined as the extent to which patients' medication-taking behavior corresponds with an agreed medication regimen from a health care provider.,18 There is no gold standard to measure medication adherence, but a variety of methods have been used in the HF population. The most common measures have included prescription refill history of HF medications through prescription insurance claims data, use of Medication Event Monitoring System (MEMS), patient self-report through questionnaires, pill counts, or serum drug levels. ${ }^{19}$

Studies evaluating predictors associated with medication adherence used at least 1, or a combination of these strategies, to assess adherence. Two reviews have described various factors related to medication adherence in HF patients, ${ }^{7,20}$ based on the 5-dimension adherence model initially described by the World Health Organization (WHO).$^{18}$ The categories affecting adherence include patient, condition, therapy or treatment, socioeconomic factors, and health-system related factors. Regression modeling using multivariate analysis to account for confounding variables was typically used to determine significant predictors of medication adherence or nonadherence. A summarized list of predictors found to significantly affect medication adherence to HF medications is presented in Table 1 and organized based on the framework of the WHO dimensions. ${ }^{6,8,10,12,21-32}$ Table 1 may assist the health care provider in recognizing predictors that may impact adherence to HF medications. Table 2 depicts a summary of the studies identifying predictors of decreased ${ }^{6,8,10,21-26,28,29,32}$ and increased ${ }^{8,12,22,26-28,30,31}$ HF medication adherence.

Large, observational cohort studies extracting adherence and demographic data from health insurance claims databases or HF registries with 2 to 4 years of follow-up data from the United States found some similar significant predictors for nonadherence, including male gender or nonwhite race. ${ }^{6,23}$ Smaller cohort studies in U.S. patients had similar findings regarding race, where minority or nonwhite race were significant predictors for nonadherence. ${ }^{8,21}$ Other interesting findings from large cohort studies with follow-up ranging from 1 to 5 years in the United States, ${ }^{6,23,32}$ Canada, ${ }^{29}$ and European countries ${ }^{22,27}$ identified those with more severe $\mathrm{HF}^{27}$ a greater 
TABLE 1 Significant Predictors Associated with Adherence to HF Medications

\begin{tabular}{|c|c|c|}
\hline $\begin{array}{l}\text { WHO Dimensions } \\
\text { Affecting Adherence }\end{array}$ & Associated with Decreased Adherence & Associated with Increased Adherence \\
\hline Patient-related factors & $\begin{array}{l}\text { Race } \\
\text { - Minorities } 21 \\
\text { - Nonwhite } \\
\text { - African American } 8,23 \\
\text { Gender } \\
\text { - Female } 22 \\
\text { - Male } 6,23,24 \\
\text { Lapses in attention } 24 \\
\text { Excessive daytime sleepiness with or without mild cognitive decline } 24,25\end{array}$ & $\begin{array}{l}\text { Advanced age }(\geq 65 \text { years })^{29} \\
\text { Gender } \\
\text { - Female } 29 \\
\text { Education level (number of years) } 26\end{array}$ \\
\hline Condition-related factors & $\begin{array}{l}\text { Increased severity of } \mathrm{HF}^{27} \\
\text { Greater number of concomitant illnesses } 22 \\
\text { Depression } 28 \\
\text { Higher heart rate }{ }^{22} \\
\text { Poor renal function }{ }^{12,23} \text { or being on dialysis } 23 \\
\text { Smoker6,10 } \\
\text { Hospitalization } \\
\text { - Previous hospitalization for any reason } 23 \\
\text { - Within } 6 \text { months of initial admission for HF } 29\end{array}$ & $\begin{array}{l}\text { Hospitalization } \\
\text { • Previous HF admission } 12\end{array}$ \\
\hline $\begin{array}{l}\text { Therapy or treatment-related } \\
\text { factors }\end{array}$ & $\begin{array}{l}\text { Increased frequency of HF medication dosing (at least twice daily) } \\
\text { Patient-reported changes to daily routine to accommodate HF } \\
\text { medication schedule } 10 \\
\text { Antiarrhythmic use } 27\end{array}$ & $\begin{array}{l}\text { Prior use of same class of HF medication } 23,27,29 \\
\text { Concurrent use of cardiac medications }{ }^{29} \\
\text { Concomitant medications }{ }^{27} \\
\text { Patient knowledge of correct dosing times }{ }^{8}\end{array}$ \\
\hline $\begin{array}{l}\text { Socioeconomic-related } \\
\text { factors }\end{array}$ & $\begin{array}{l}\text { Living alone }{ }^{27} \\
\text { Patient income } \\
\text { No health insurance } \\
\end{array}$ & $\begin{array}{l}\text { Health literacy }{ }^{30} \\
\text { Reading ability } \\
\text { Marital status-married } \\
\end{array}$ \\
\hline Health systems-related factors & Increase in medication copay 32 & \\
\hline
\end{tabular}

number of concomitant illnesses, ${ }^{22}$ living alone, ${ }^{22}$ no health insurance, ${ }^{6}$ higher medication copays, ${ }^{32}$ or hospitalization within 6 months of their initial HF admission ${ }^{29}$ as significant predictors for nonadherence to HF medications. Two smaller observational studies that followed patients for 3 to 6 months found that twice daily dosing of medication increased the likelihood of nonadherence to HF medications. ${ }^{10,25}$ Some of these large cohort studies were in agreement that prior use of the same class of HF medication was a significant predictor for improved medication adherence. ${ }^{23,27,29}$ Interestingly, 2 of these large cohort studies found that concomitant use of at least 3 cardiac medications was a significant predictor for medication adherence. ${ }^{27,29}$ Smaller observational studies that measured medication adherence over a 6-to 9-month period with the ability to administer surveys to patients found that reading ability, ${ }^{8}$ measured by a reading score assigned after patients complete a medication skills assessment survey, and health literacy, ${ }^{30}$ measured by using the reading component of the Short Test of Functional Health Literacy in Adults, were positive predictors for adherence.
Predictor studies from large claims or registry data suggest that clinicians should be aware of racial, social, and financial disparities that may contribute to nonadherence. Recent hospitalization and a greater number of patient comorbidities have also been shown to be predictors for nonadherence. However, providers have assurance that previous exposure to a medication in the same class or even being on multiple cardiac medications along with HF medication improve medication adherence. Further research should be conducted to evaluate the impact of health literacy and patient understanding, as smaller studies show that these correlate with better medication adherence.

Few studies have further evaluated whether a particular predictor, with or without a factor of medication adherence, affected clinical or economic outcomes. Wu et al. (2012) conducted a series of studies in HF patients to determine factors affecting event-free survival, factors defined as ED visits for symptoms of decompensated HF, HF or cardiac hospitalizations, and all-cause mortality. ${ }^{31}$ The studies found that those who were not married $(P=0.044),{ }^{31}$ those with low perceived social support combined with nonadherence to HF 


\section{TABLE 2 Studies Assessing Predictors of Decreased or Increased Adherence to HF Medication}

\begin{tabular}{|c|c|c|c|c|}
\hline $\begin{array}{l}\text { Author, Year, } \\
\text { Country }\end{array}$ & $\begin{array}{c}\text { Design and Number } \\
\text { of HF Patients }\end{array}$ & $\begin{array}{l}\text { Follow-up } \\
\text { Time Period }\end{array}$ & $\begin{array}{l}\text { Predictor of Adherence Decrease, } \\
\text { Odds Ratio, Risk Ratio, or Hazard Ratio } \\
\text { (95\% CI) If Reported, P Value }\end{array}$ & $\begin{array}{l}\text { Predictor of Adherence Increase, } \\
\text { Odds Ratio, Risk Ratio, or Hazard Ratio } \\
(95 \% \text { CI) If Reported, } P \text { Value }\end{array}$ \\
\hline $\begin{array}{l}\text { Gislason, } 2007^{27} \\
\text { Denmark }\end{array}$ & $\begin{array}{l}\text { Observational, } \\
\mathrm{n}=107,092 \text { (patients } \\
\text { using Danish Registry } \\
\text { of Medicinal Product } \\
\text { Statistics) }\end{array}$ & $\begin{array}{l}\text { Up to } 5 \\
\text { years }\end{array}$ & $\begin{array}{l}\text { Increased severity of HF (requiring }>160 \\
\text { mg/day of loop diuretic), HR } 1.14 \text { ( } 1.05- \\
1.24), P=0.002 \text { for nonadherence to ACEI/ } \\
\text { ARB } \\
\text { Living alone, HR } 1.06(1.01-1.12), P=0.02 \\
\text { for nonadherence to BB; HR } 1.08(1.04- \\
1.13), P=0.0003 \text { for nonadherence to } \\
\text { ACEI/ARB }\end{array}$ & $\begin{array}{l}\text { Prior use of same class of HF medica- } \\
\text { tion, HR } 0.75(0.71-0.79), P<0.0001 \text { for } \\
\text { nonadherence to BB; HR } 0.86(0.83-0.90), \\
P<0.0001 \text { for nonadherence to ACEI/ARB } \\
\text { Concomitant medications ( } 3 \text { drugs), HR } 0.75 \\
(0.66-0.84), P<0.0001 \text { for nonadherence } \\
\text { to BB; HR } 0.84(0.74-0.96), P=0.01 \text { for } \\
\text { nonadherence to ACEI/ARB } \\
\text { Concomitant medications ( } 2 \text { drugs), HR } \\
0.80 \text { ( } 0.75-0.86), P<0.0001 \text { for nonadher- } \\
\text { ence to BB }\end{array}$ \\
\hline $\begin{array}{l}\text { Ambardekar, } 20096 \\
\text { United States }\end{array}$ & $\begin{array}{l}\text { Observational cohort, } \\
\mathrm{n}=54,322 \text { (patients } \\
\text { from the Get With } \\
\text { The Guidelines-Heart } \\
\text { Failure registry, } 236 \\
\text { participating sites) }\end{array}$ & 2 years & $\begin{array}{l}\text { Male, OR } 1.274(1.196-1.358), P<0.0001 \\
\text { for nonadherence } \\
\text { Nonwhite, OR } 1.489(1.358-1.632) \\
P<0.0001 \text { for nonadherence } \\
\text { Smoker, OR } 1.683(1.562-1.814), P<0.0001 \\
\text { for nonadherence } \\
\text { No health insurance, OR } 1.421 \text { ( } 1.236- \\
1.633), P<0.0001 \text { for nonadherence }\end{array}$ & \\
\hline $\begin{array}{l}\text { Setogouchi, } 2010^{23} \\
\text { United States }\end{array}$ & $\begin{array}{l}\text { Observational, } \\
\mathrm{n}=46,278 \text { (data from } \\
\text { Medicare beneficiaries } \\
\text { from } 2 \text { statewide } \\
\text { pharmacy benefit } \\
\text { programs) }\end{array}$ & $\begin{array}{l}1.5 \text { to } \\
3.8 \text { years }\end{array}$ & 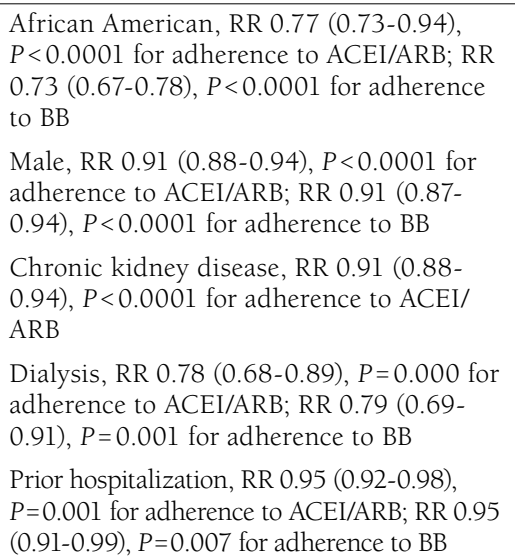 & $\begin{array}{l}\text { Prior ACEI/ARB use, RR } 1.12(1.09-1.15), \\
P<0.0001 \text { for adherence to ACEI/ARB } \\
\text { Prior BB use, RR } 1.13(1.09-1.17), P<0.0001 \\
\text { for adherence to BB }\end{array}$ \\
\hline $\begin{array}{l}\text { Lamb, } 2009^{29} \\
\text { Canada }\end{array}$ & $\begin{array}{l}\text { Observational cohort, } \\
\mathrm{n}=14,198 \text { (patients } \\
\text { using beneficiary data- } \\
\text { bases from } 1 \text { province } \\
\text { in Canada) }\end{array}$ & $\begin{array}{l}\text { Up to } \\
12 \text { months }\end{array}$ & $\begin{array}{l}\text { Renal failure, OR } 0.74(0.58-0.93), P=0.01 \\
\text { for adherence to ACEI/ARB } \\
\text { Hospitalization within } 6 \text { months of ini- } \\
\text { tial HF admission, OR } 0.87(0.77-0.98) \text {, } \\
P=0.02 \text { for adherence to ACEI/ARB } \\
\text { Elderly ( } \geq 65 \text { years of age), OR } 0.70(0.51- \\
0.97), P=0.03 \text { for adherence to BB } \\
\text { Antiarrhythmic use, OR } 0.60(0.43-0.85) \text {, } \\
P=0.003 \text { for adherence to BB } \\
\text { Hospitalization within } 6 \text { months of ini- } \\
\text { tial HF admission, OR } 0.56(0.44-0.72) \text {, } \\
P=0.0001 \text { for adherence to BB }\end{array}$ & $\begin{array}{l}\text { Elderly ( } \geq 65 \text { years of age), OR } 1.26 \text { (1.06- } \\
1.50), P=0.01 \text { for adherence to ACEI/ARB } \\
\text { Female, OR } 1.19 \text { ( } 1.05-1.34), P=0.005 \text { for } \\
\text { adherence to ACEI/ARB } \\
\text { Prior use of ACEI/ARB, OR } 1.73(1.53-1.95) \text {, } \\
P=0.0001 \text { for adherence to ACEI/ARB } \\
\text { Concurrent use of cardiac medications } \\
\text { (at least 3), OR } 1.20 \text { ( } 1.02-1.40), P=0.02 \text { for } \\
\text { adherence to ACEI/ARB } \\
\text { Prior use of BB, OR } 1.32(1.02-1.70), P=0.03 \\
\text { for adherence to BB } \\
\text { Concurrent use of cardiac medications } \\
\text { (at least } 3 \text { ), OR } 1.31 \text { ( } 1.01-1.71), P=0.04 \text { for } \\
\text { adherence to BB }\end{array}$ \\
\hline $\begin{array}{l}\text { Cole, } 2006^{32} \\
\text { United States }\end{array}$ & $\begin{array}{l}\text { Observational cohort, } \\
\mathrm{n}=11,003 \text { (patients } \\
\text { using pharmacy } \\
\text { claims data from } \\
\text { commercial and/or } \\
\text { Medicare plans) }\end{array}$ & $\begin{array}{l}\text { Up to } 12 \\
\text { months }\end{array}$ & $\begin{array}{l}\$ 10 \text { increase in medication copay for ACEI } \\
\text { associated with a } 2.6 \% \text { decrease in adher- } \\
\text { ence, } 95 \% \mathrm{CI}=2.0-3.1,{ }^{\mathrm{a}} \text { no specific OR or } P \\
\text { value reported } \\
\$ 10 \text { increase in medication copay for BB } \\
\text { associated with a } 1.8 \% \text { decrease in adher- } \\
\text { ence, } 95 \% \mathrm{CI}=1.4-2.2,{ }^{\text {a }} \text { no specific OR or } P \\
\text { value reported }\end{array}$ & \\
\hline
\end{tabular}


TABLE 2 Studies Assessing Predictors of Decreased or Increased Adherence to HF Medication (continued)

\begin{tabular}{|c|c|c|c|c|}
\hline $\begin{array}{l}\text { Author, Year, } \\
\text { Country }\end{array}$ & $\begin{array}{l}\text { Design and Number } \\
\text { of HF Patients }\end{array}$ & $\begin{array}{l}\text { Follow-up } \\
\text { Time Period }\end{array}$ & $\begin{array}{l}\text { Predictor of Adherence Decrease, } \\
\text { Odds Ratio, Risk Ratio, or Hazard Ratio } \\
\text { (95\% CI) If Reported, P Value }\end{array}$ & $\begin{array}{c}\text { Predictor of Adherence Increase, } \\
\text { Odds Ratio, Risk Ratio, or Hazard Ratio } \\
\text { (95\% CI) If Reported, } P \text { Value }\end{array}$ \\
\hline $\begin{array}{l}\text { Granger, } 2009^{22} \\
\text { Multiple }\end{array}$ & $\begin{array}{l}\text { Observational cohort, } \\
\mathrm{n}=7,599 \text { (CHARM } \\
\text { trial that enrolled } \\
\text { patients from } 618 \text { sites } \\
\text { in } 25 \text { participating } \\
\text { countries) }\end{array}$ & $\begin{array}{c}\text { Median } \\
38 \text { months }\end{array}$ & $\begin{array}{l}\text { Female, no OR or RR reported, B coeffi- } \\
\text { cient }-0.049 \text { for adherence, } P=0.000 \\
\text { Greater number of concomitant illnesses, } \\
\text { no OR or RR reported, B coefficient }-0.041 \\
\text { for adherence, } P=0.001 \\
\text { Higher heart rate, no OR or RR reported, B } \\
\text { coefficient }-0.051 \text { for adherence, } P=0.000\end{array}$ & \\
\hline $\begin{array}{l}\text { Calvin, } 2012^{21} \\
\text { United States } \\
\end{array}$ & $\begin{array}{l}\text { Observational cohort, } \\
\mathrm{n}=692\end{array}$ & $2-3$ years & $\begin{array}{l}\text { Minority, OR } 3.18 \text { (2.11-4.78), } P<0.0001 \\
\text { for nonadherence }\end{array}$ & \\
\hline $\begin{array}{l}\text { George, } 2007^{10} \\
\text { Canada }\end{array}$ & $\begin{array}{l}\text { Observational cohort, } \\
\mathrm{n}=350\end{array}$ & $\begin{array}{l}\text { At least } \\
3 \text { months }\end{array}$ & $\begin{array}{l}\text { Smoker, OR } 2.42(1.02-5.75), P=0.045 \text { for } \\
\text { nonadherence } \\
\text { Use of medications twice daily or less fre- } \\
\text { quently, OR } 2.35(1.20-4.60), P=0.01 \text { for } \\
\text { nonadherence } \\
\text { Patients reported changes to daily routine } \\
\text { to accommodate HF medication schedules, } \\
\text { OR } 2.35 \text { (1.23-4.52), } P=0.01 \text { for nonadher- } \\
\text { ence }\end{array}$ & \\
\hline $\begin{array}{l}\text { Hansen, } 2009^{28} \\
\text { United States }\end{array}$ & $\begin{array}{l}\text { Observational cohort, } \\
\mathrm{n}=314\end{array}$ & 12 months & $\begin{array}{l}\text { Depression, no OR or RR reported, } \\
P<0.001 \text { for nonadherence } \\
\text { Income, no OR or RR reported, } P<0.001 \\
\text { for nonadherence }\end{array}$ & \\
\hline $\begin{array}{l}\text { Noureldin, } 2012^{30} \\
\text { United States }\end{array}$ & $\begin{array}{l}\text { Observational cohort, } \\
\mathrm{n}=281\end{array}$ & 9 months & & $\begin{array}{l}\text { Health literacy level, no OR or RR reported, } \\
P<0.0001 \text { for taking adherence and } \\
P=0.001 \text { for scheduling adherence }\end{array}$ \\
\hline $\begin{array}{l}\text { Riegel, } 2012^{24} \\
\text { United States }\end{array}$ & $\begin{array}{l}\text { Observational cohort } \\
\text { comparison, } \mathrm{n}=280\end{array}$ & 6 months & $\begin{array}{l}\text { Excessive daytime sleepiness, OR } 2.51 \\
\text { (1.06-5.95), } P=0.037 \text { for nonadherence } \\
\text { Two or more medication dosings per day, OR } \\
2.59 \text { (1.14-5.64), } P=0.016 \text { for nonadherence } \\
\text { Lapses in attention on psychomotor vigi- } \\
\text { lance task, OR } 2.65 \text { (1.14-6.16), } P=0.023 \\
\text { for nonadherence }\end{array}$ & \\
\hline $\begin{array}{l}\text { Riegel, } 2011^{25} \\
\text { United States }\end{array}$ & $\begin{array}{l}\text { Observational cohort } \\
\text { comparison, } \mathrm{n}=280\end{array}$ & 6 months & $\begin{array}{l}\text { Excessive daytime sleepiness without mild } \\
\text { cognitive decline, OR } 0.58(0.37-0.90), \\
P=0.014 \text { for adherence } \\
\text { Excessive daytime sleepiness with mild } \\
\text { cognitive decline, OR } 0.62(0.40-0.97) \\
P=0.037 \text { for adherence }\end{array}$ & \\
\hline $\begin{array}{l}\text { Mockler, } 200912 \\
\text { Ireland }\end{array}$ & $\begin{array}{l}\text { Observational cohort, } \\
\mathrm{n}=183\end{array}$ & $\begin{array}{l}\text { Up to } \\
2 \text { years }\end{array}$ & $\begin{array}{l}\text { Creatinine, HR } 1.019(1.008-1.030) \\
P=0.005 \text { for nonadherence }\end{array}$ & $\begin{array}{l}\text { Previous HF admission, HR } 0.314(0.138- \\
0.716), P=0.006 \text { for nonadherence }\end{array}$ \\
\hline $\begin{array}{l}\text { Wu, 201231 } \\
\text { United States }\end{array}$ & $\begin{array}{l}\text { Observational cohort, } \\
\mathrm{n}=136\end{array}$ & 3 months & & $\begin{array}{l}\text { A marital status of married, no OR or RR } \\
\text { reported, } P=0.033 \text { for adherence }\end{array}$ \\
\hline $\begin{array}{l}\text { Hope, } 2004^{8} \\
\text { United States }\end{array}$ & $\begin{array}{l}\text { Observational cohort, } \\
\mathrm{n}=61\end{array}$ & 6 months & $\begin{array}{l}\text { African American, OR } 0.16(0.06-0.43) \text {, } \\
P<0.001 \text { for adherence }\end{array}$ & $\begin{array}{l}\text { Patient knowledge of correct dosing times, } \\
\text { OR } 3.46 \text { (1.66-7.22), } P=0.001 \text { for adherence } \\
\text { Reading ability, OR } 2.92 \text { (1.12-7.64), } \\
P=0.029 \text { for adherence }\end{array}$ \\
\hline $\begin{array}{l}\text { Chui, } 2003^{26} \\
\text { United States } \\
\end{array}$ & $\begin{array}{l}\text { Observational cohort, } \\
\mathrm{n}=42\end{array}$ & 6 months & & $\begin{array}{l}\text { Patient level of education, no OR or RR } \\
\text { reported, } P=0.0069 \text { for adherence }\end{array}$ \\
\hline
\end{tabular}

${ }^{a}$ Ordinary least-squares regression was used to analyze adherence as a function of copayment.

$A C E I=$ angiotensin-converting enzyme inhibitor; $A R B=$ angiotensin-receptor blocker; $B B=$ beta blockers; $C H A R M=$ Candesartan in Heart Failure Assessment of Reduction in Mortality and Morbidity study; $C I=$ confidence interval; $H F=$ heart failure; $H R=$ hazard ratio; $m g /$ day = milligrams per day; $O R=o d d s$ ratio; $R R=$ risk ratio. 
medications $(P=0.02),{ }^{31}$ and nonwhite race $(P=0.026)$ were more likely to experience a cardiac-related event. ${ }^{31,33,34}$ Perceived social support was measured using the Multidimensional Perceived Social Support Scale, ${ }^{35}$ which is a self-administered, 12-item Likert scale to determine the patient's beliefs about social support from family, friends, or significant others.

Only 1 study, Cole et al. (2006), evaluated the impact of medication copay on medication adherence in the HF population. ${ }^{32}$ This study used prescription and medication claims data to estimate medication costs as predictors of adherence. Cole et al. found that every $\$ 10$ increase in medication copay predicted a 2.6\% decrease in adherence to angiotensin-converting enzyme inhibitor (ACEI) therapy, with the change in adherence associated with a predicted $0.8 \%$ reduction in medical costs and $6.1 \%$ increase in hospitalizations for HF. Similar findings were found with a $\$ 10$ increased copay for beta blocker (BB) therapy that predicted a 1.8\% decrease in adherence, with the change in adherence associated with a predicted $2.8 \%$ reduction in medical costs and $8.7 \%$ increase in hospitalizations for HF. ${ }^{32}$

Many significant predictors have been identified that affect adherence to HF medications. Based on the WHO 5-dimension adherence model, the majority of predictors are patient-related, condition-related, or treatment-related factors. Less research is available on socioeconomic-related and health systems-related factors that may predict adherence in HF patients, but 1 study has shown that medication copays impact economic and clinical outcomes in this population. ${ }^{32}$ Clinicians should be aware of these predictors to develop possible solutions for any modifiable predictors to improve adherence to HF medications.

\section{Pharmacist Interventions to Improve Adherence}

Pharmacists play an important role in HF patients' care. Randomized controlled studies have shown that pharmacists improve medication and lifestyle adherence as part of a multidisciplinary team. ${ }^{36-40}$ Some of these studies also demonstrated improvements in patients' clinical outcomes. ${ }^{36,37,39-41}$

\section{Studies Assessing Medication Adherence}

A summary of studies evaluating pharmacist interventions on medication adherence is presented in Table $3 .{ }^{36-44}$ One of the earliest randomized controlled trials that assessed the effect of intensive pharmacist counseling randomized 100 elderly patients with stable HF in the United Kingdom to a 3 -month pharmacist counseling intervention versus standard care..$^{40}$ Medication adherence, per pill count, was $93 \%$ for the intervention group and $51 \%$ for the control group post-intervention $(P<0.001)$. Medication knowledge scores significantly improved in the intervention group, but not in the control group, in the areas of awareness of name, purpose, dose, and adverse effects of medication. More patients in the intervention group (81\%) had no edema at the end of the study when compared with the control group (49\%; $P<0.05)$. The 6-minute walk test also improved for the intervention group by 20 meters but worsened by 22 meters for the control group $(P<0.001)$. However, no correlation was found $(r=0.28, P>0.05)$ between exercise improvement and medication adherence in the intervention group.

Another early randomized controlled pilot study assessed the impact of a year-long structured pharmaceutical care program in 83 patients at 3 sites in Northern Ireland. ${ }^{41}$ Patients were randomized to a pharmacist education intervention at baseline and every 3 months, plus daily weight recordings, versus usual care. Adherence, as measured by patient-reported data, showed no significant differences between the 2 groups. Adherence data, as measured by drug use profiles from refill records, were only available from a limited number of patients, making it difficult to draw conclusions about adherence from this study. Intervention patients did demonstrate significantly better medication knowledge than control patients at 12 months $(P<0.05)$ and had 14 hospital admissions versus 27 for control patients $(P=0.006)$.

Bouvy et al. (2003) assessed the effect of 6 months of monthly consultation from a community pharmacist on loop diuretic adherence in a randomized controlled trial in 152 patients in the Netherlands. ${ }^{38}$ Adherence, as measured by MEMS, was significantly greater in the intervention group, which had 140 of 7,656 days without diuretics versus 337 of 6,196 days for controls (relative risk $[R R]=0.33,95 \%$ $\mathrm{CI}=0.24-0.38$ ). There were no significant differences between the 2 groups in mortality (14\% intervention vs. $21 \%$ control, $\mathrm{RR}=0.6,95 \% \mathrm{CI}=0.3-1.4$ ) or number of rehospitalizations (32 intervention vs. 42 control, $P=0.4$ ). However, this study was underpowered to demonstrate changes in clinical outcomes.

Another randomized, controlled, single-blinded pilot study in $134 \mathrm{HF}$ patients in Canada assessed the impact of a single multidisciplinary educational intervention versus usual care. ${ }^{42}$ Intervention patients received extensive multidisciplinary HF education at discharge, and all patients were followed every 3 months for outcomes assessment for 1 year. Adherence was recorded through refill records, patient diaries, and MEMS. Though not statistically significant, there were trends towards less nonadherence in the intervention group compared with controls for ACEI/ARB (angiotensin-receptor blocker; $\mathrm{RR}=0.78,95 \% \mathrm{CI}=0.33-1.89), \mathrm{BB}(\mathrm{RR}=0.89,95 \% \mathrm{CI}=0.28$ 2.82), and digoxin ( $\mathrm{RR}=0.79,95 \% \mathrm{CI}=0.25-2.51)$. Though not powered to detect, the composite endpoint of all-cause mortality, hospital admissions, and ED visits was not significantly different between the 2 groups (intervention $60 \%$, control $67 \%, \mathrm{HR}=0.85,95 \% \mathrm{CI}=0.55-1.40)$.

Sadik et al. (2005) assessed structured pharmaceutical care versus traditional care in $208 \mathrm{HF}$ patients in the United Arab Emirates. ${ }^{36}$ The intervention integrated a treatment algorithm, patient education, and self-monitoring through diary cards. 


\section{TABLE 3 Pharmacist Intervention Studies Assessing Medication Adherence}

\begin{tabular}{|c|c|c|c|c|c|c|}
\hline $\begin{array}{l}\text { Author, Year, } \\
\text { Country }\end{array}$ & $\begin{array}{c}\text { Design and Number } \\
\text { of Patients }\end{array}$ & Control & $\begin{array}{l}\text { Description of } \\
\text { Intervention }\end{array}$ & $\begin{array}{l}\text { Follow-up } \\
\text { Duration }\end{array}$ & Adherence Outcome & Other Major Outcomes \\
\hline $\begin{array}{l}\text { Goodyer, } \\
1995^{40} \\
\text { United } \\
\text { Kingdom }\end{array}$ & $\begin{array}{l}\text { Prospective, } \\
\text { randomized, } \\
\text { controlled, } \\
\mathrm{n}=100\end{array}$ & Usual care & $\begin{array}{l}\text {-month } \\
\text { pharmacist } \\
\text { counseling }\end{array}$ & 3 months & $\begin{array}{l}\text { Per pill count: } 93 \% \text { for } \\
\text { intervention and } 51 \% \text { for } \\
\text { control }(P<0.01)\end{array}$ & $\begin{array}{l}\text { Significant improvement in medi- } \\
\text { cation knowledge for intervention } \\
\text { group but not control }(P<0.001) \text {; } \\
\text { intervention patients with no } \\
\text { edema } 81 \% \text { versus control } 49 \% \\
(P<0.05) ; 6 \text {-minute walk test for } \\
\text { intervention patients improved by } \\
20 \text { m but worsened by } 22 \text { m for } \\
\text { control }(P<0.001)\end{array}$ \\
\hline $\begin{array}{l}\text { Varma, 199941 } \\
\text { Northern } \\
\text { Ireland }\end{array}$ & $\begin{array}{l}\text { Prospective, } \\
\text { randomized, } \\
\text { controlled, } \\
\mathrm{n}=83\end{array}$ & Usual care & $\begin{array}{l}\text { Baseline and } \\
\text { every } 3 \text { months } \\
\text { pharmacist } \\
\text { education }\end{array}$ & 12 months & $\begin{array}{l}\text { Patient-reported data } \\
\text { showed no significant } \\
\text { difference, limited patient } \\
\text { refill data }\end{array}$ & $\begin{array}{l}\text { Significantly better medication } \\
\text { knowledge for intervention group } \\
\text { but not control }(P<0.05) \text {; inter- } \\
\text { vention patients had } 14 \text { hospital } \\
\text { admissions versus } 27 \text { for control } \\
(P=0.006)\end{array}$ \\
\hline $\begin{array}{l}\text { Bouvy, } 2003^{38} \\
\text { Netherlands }\end{array}$ & $\begin{array}{l}\text { Prospective, } \\
\text { randomized, } \\
\text { controlled, } \\
\mathrm{n}=152\end{array}$ & Usual care & $\begin{array}{l}\text { Monthly } \\
\text { pharmacist } \\
\text { consultation }\end{array}$ & 6 months & $\begin{array}{l}\text { Per MEMS: significantly } \\
\text { greater in intervention } \\
\text { group ( } 140 / 7,656 \text { days } \\
\text { without diuretics) ver- } \\
\text { sus control }(337 / 6,196 \\
\text { days without diuretics; } \\
\mathrm{RR}=0.33,95 \% \mathrm{CI}=0.24- \\
0.38)\end{array}$ & $\begin{array}{l}\text { No significant differences in mor- } \\
\text { tality ( } 14 \% \text { intervention vs. } 21 \% \\
\text { control, } \mathrm{RR}=0.6,95 \% \mathrm{CI}=0.3-1.40 \text { ) } \\
\text { or rehospitalizations ( } 32 \text { intervention } \\
\text { vs. } 42 \text { control, } P=0.4 \text { ) }\end{array}$ \\
\hline $\begin{array}{l}\text { Gwadry-Sridhar, } \\
2005^{42} \\
\text { Canada }\end{array}$ & $\begin{array}{l}\text { Prospective, } \\
\text { randomized, } \\
\text { controlled, } \\
\text { single-blinded, } \\
\mathrm{n}=134\end{array}$ & Usual care & $\begin{array}{l}\text { Single, multidisci- } \\
\text { plinary education } \\
\text { intervention }\end{array}$ & 12 months & $\begin{array}{l}\text { Per refill records, patient } \\
\text { diaries, and MEMS: } \\
\text { trends towards less } \\
\text { nonadherence in the } \\
\text { intervention group com- } \\
\text { pared with controls for } \\
\text { ACEI/ARB (RR }=0.78 \text {, } \\
95 \% \mathrm{CI}=0.33-1.89) \text {, BB } \\
(\mathrm{RR}=0.89,95 \% \mathrm{CI}=0.28 \text { - } \\
2.82) \text {, and digoxin } \\
(\mathrm{RR}=0.79,95 \% \mathrm{CI}=0.25 \text { - } \\
2.51)\end{array}$ & $\begin{array}{l}\text { No significant differences in } \\
\text { composite endpoint of all-cause } \\
\text { mortality, hospital admissions, and } \\
\text { ED visits (intervention } 60 \% \text {, control } \\
67 \%, \mathrm{HR}=0.85,95 \% \mathrm{CI}=0.55-1.40 \text { ) }\end{array}$ \\
\hline $\begin{array}{l}\text { Sadik, } 2005^{36} \\
\text { United Arab } \\
\text { Emirates }\end{array}$ & $\begin{array}{l}\text { Prospective, } \\
\text { randomized, } \\
\text { controlled, } \\
\mathrm{n}=208\end{array}$ & Usual care & $\begin{array}{l}\text { Pharmacist educa- } \\
\text { tion, treatment } \\
\text { algorithm, and } \\
\text { self-monitoring }\end{array}$ & 12 months & $\begin{array}{l}\text { Per patient reported } \\
\text { data: } 82 \% \text { in interven- } \\
\text { tion versus } 34 \% \text { control, } \\
P<0.05 \text {, lifestyle adjust- } \\
\text { ment adherence } 72 \% \text { in } \\
\text { intervention versus } 28 \% \\
\text { control, } P<0.05\end{array}$ & $\begin{array}{l}\text { Significantly greater } 2 \text {-minute } \\
\text { walk test distance, at } 6,9 \text {, and } 12 \\
\text { months for intervention versus con- } \\
\text { trol ( } 136.1 \mathrm{~m} \text { vs. } 114.6 \mathrm{~m}, P=0.011 \text {; } \\
138.5 \mathrm{~m} \text { vs. } 115.4 \mathrm{~m}, P=0.006 \text {; } \\
140.2 \mathrm{~m} \text { vs. } 117.2 \mathrm{~m}, P=0.001 \text {, } \\
\text { respectively); significant improve- } \\
\text { ments in FVC, for intervention ver- } \\
\text { sus control at } 6,9 \text {, and } 12 \text { months; } \\
\text { significantly better perceived qual- } \\
\text { ity of life in intervention versus } \\
\text { control (summary AUC }=463.5 \text {, } \\
95 \% \mathrm{CI}=433.2-493.9 \text { vs. } 637.5 \text {, } \\
95 \% \mathrm{CI}=597.2-677.7, P<0.05) ; \\
\text { trends towards reduced hospital } \\
\text { admissions }(22 \text { intervention vs. } \\
36 \text { control), albeit an increase in } \\
\text { office visits ( } 33 \text { intervention vs. } 25 \\
\text { control) }\end{array}$ \\
\hline $\begin{array}{l}\text { Lopez Cabezas, } \\
2006^{37} \\
\text { Spain }\end{array}$ & $\begin{array}{l}\text { Prospective, } \\
\text { randomized, } \\
\text { controlled, } \\
\mathrm{n}=134\end{array}$ & Usual care & $\begin{array}{l}\text { Postdischarge } \\
\text { pharmaceutical } \\
\text { care plus teleman- } \\
\text { agement (monthly } \\
\text { for } 6 \text { months, then } \\
\text { every } 2 \text { months) }\end{array}$ & 12 months & $\begin{array}{l}\text { Per pill counts: higher in } \\
\text { the intervention group at } \\
\text { all time points assessed } \\
\text { ( } 2,6 \text {, and } 12 \text { months), } \\
\text { statistically significant } \\
\text { at } 2 \text { months ( } 88.2 \% \text { vs. } \\
60.5 \%, P=0.002) \text { and } 6 \\
\text { months }(91.1 \% \text { vs. } 69.0 \% \text {, } \\
P=0.015)\end{array}$ & $\begin{array}{l}\text { Significantly less mortality at } 12 \\
\text { months ( } 12.9 \% \text { intervention vs. } \\
29.7 \% \text { control, } P=0.017) \text {; percent- } \\
\text { age of patients readmitted, number } \\
\text { of readmissions, and hospital stay } \\
\text { days all lower in intervention group } \\
\text { versus control, statistically signifi- } \\
\text { cant at } 2 \text { and } 6 \text { months but not at } \\
12 \text { months }\end{array}$ \\
\hline
\end{tabular}




\section{TABLE 3 Pharmacist Intervention Studies Assessing Medication Adherence (continued)}

\begin{tabular}{|c|c|c|c|c|c|c|}
\hline $\begin{array}{l}\text { Author, Year, } \\
\text { Country }\end{array}$ & $\begin{array}{l}\text { Design and Number } \\
\text { of Patients }\end{array}$ & Control & $\begin{array}{l}\text { Description of } \\
\text { Intervention }\end{array}$ & $\begin{array}{l}\text { Follow-up } \\
\text { Duration }\end{array}$ & Adherence Outcome & Other Major Outcomes \\
\hline $\begin{array}{l}\text { Murray, } 200739 \\
\text { United States }\end{array}$ & $\begin{array}{l}\text { Prospective, } \\
\text { randomized, } \\
\text { controlled, } \\
\mathrm{n}=314\end{array}$ & Usual care & $\begin{array}{l}\text { Ambulatory multi- } \\
\text { disciplinary pro- } \\
\text { tocol, including } \\
\text { pharmacist medi- } \\
\text { cation reconcilia- } \\
\text { tion, assessment of } \\
\text { patient knowledge } \\
\text { and skills, provi- } \\
\text { sion of medica- } \\
\text { tions, and educa- } \\
\text { tion, 9-month } \\
\text { intervention }\end{array}$ & 12 months & $\begin{array}{l}\text { Per MEMS and refill } \\
\text { records: at } 9 \text { months } \\
67.9 \%, 95 \% \mathrm{CI}=63.8- \\
72.1 \text { control and } 78.8 \% \text {, } \\
95 \% \mathrm{CI}=74.9-82.7 \\
\text { intervention, a signifi- } \\
\text { cant difference of } 10.9 \% \text {, } \\
95 \% \mathrm{CI}=5.0-16.7 \text {; at } 12 \\
\text { months, no longer signifi- } \\
\text { cant ( } 3.9 \%, 95 \% \mathrm{CI}=-2.8- \\
10.7) \text {; significantly better } \\
\text { medication timing adher- } \\
\text { ence at } 9 \text { months for } \\
\text { intervention }(5.9 \%, 95 \% \\
\mathrm{CI}=0.4-11.5) \text { but not at } \\
12 \text { months }(0.3 \%, 95 \% \\
\mathrm{CI}=-5.9-6.5)\end{array}$ & $\begin{array}{l}\text { Significantly fewer hospital admis- } \\
\text { sions and ED visits in intervention } \\
\text { versus control (IRR }=0.82,95 \% \\
C I=0.70-0.95)\end{array}$ \\
\hline $\begin{array}{l}\text { Tsuyuki, } \\
2004^{43} \\
\text { Canada }\end{array}$ & $\begin{array}{l}\text { Prospective, } \\
\text { randomized, } \\
\text { controlled, } \\
\mathrm{n}=276\end{array}$ & Usual care & $\begin{array}{l}\text { Pharmacist or } \\
\text { nurse discharge } \\
\text { intervention (edu- } \\
\text { cation and written } \\
\text { adherence aids) } \\
\text { plus follow-up at } \\
2 \text { weeks, } 4 \text { weeks, } \\
\text { and monthly for } 6 \\
\text { months total }\end{array}$ & 6 months & $\begin{array}{l}\text { Per refill records: no } \\
\text { significant difference in } \\
\text { ACEI adherence between } \\
\text { the } 2 \text { groups }(86.2 \pm 29 \% \\
\text { control vs. } 83.5 \pm 29 \% \\
\text { intervention, } P=0.691)\end{array}$ & $\begin{array}{l}\text { No differences in number of physi- } \\
\text { cian visits, ED visits, or readmis- } \\
\text { sions; significant reduction in the } \\
\text { number of cardiovascular-related } \\
\text { ED visits ( } 49 \text { control vs. } 20 \text { inter- } \\
\text { vention, } P=0.030) \text {, the total length } \\
\text { of hospital stay }(627 \text { days inter- } \\
\text { vention vs. } 1,082 \text { days control, } \\
P<0.001 \text { ), and in average length of } \\
\text { hospital stay ( } 6.6 \pm 5.5 \text { days inter- } \\
\text { vention vs. } 11.0 \pm 9.2 \text { days control, } \\
P<0.001 \text { ) }\end{array}$ \\
\hline $\begin{array}{l}\text { Eggink, } \\
2010^{44} \\
\text { Netherlands }\end{array}$ & $\begin{array}{l}\text { Prospective, } \\
\text { randomized, } \\
\text { controlled, } \\
\mathrm{n}=85\end{array}$ & Usual care & $\begin{array}{l}\text { Pharmacist dis- } \\
\text { charge service with } \\
\text { medication recon- } \\
\text { ciliation, commu- } \\
\text { nication with pro- } \\
\text { viders, and patient } \\
\text { education }\end{array}$ & 6 weeks & $\begin{array}{l}\text { No difference in medica- } \\
\text { tion nonadherence per } \\
\text { the Brief Medication } \\
\text { Questionnaire }(79.5 \% \\
\text { control vs. } 78.0 \% \text { inter- } \\
\text { vention, RR }=1.08,95 \% \\
\mathrm{CI}=0.47-2.44)\end{array}$ & - \\
\hline
\end{tabular}

$A C E I=$ angiotensin-converting enzyme inhibitor; $A R B=$ angiotensin-receptor blocker; $A U C=$ area under curve; $B B=$ beta blocker; $C I=$ confidence interval; $E D=$ emergency department; $F V C=$ forced vital capacity; $H R=$ hazard ratio; $I R R=$ inter-rater reliability; $m=$ meters; $M E M S=$ Medication Event Monitoring System; $R R=$ risk ratio.

Patients were followed for a period of 12 months. The 2-minute walk test, in meters, was significantly greater at 6,9 , and 12 months for the intervention versus control group $(136.1 \mathrm{~m}$ vs. $114.6 \mathrm{~m}, P=0.011 ; 138.5 \mathrm{~m}$ vs. $115.4 \mathrm{~m}, P=0.006 ; 140.2$ $\mathrm{m}$ vs. $117.2 \mathrm{~m}, P=0.001$, respectively). Intervention patients also showed significant improvements in forced vital capacity, when compared with the control patients at 6,9 , and 12 months. Minnesota Living with Heart Failure Questionnaire data revealed significantly better perceived quality of life in the intervention versus control patients (summary area under the curve [AUC]: intervention 463.5, 95\% CI=433.2-493.9; control $637.5,95 \% \mathrm{CI}=597.2-677.7 ; P<0.05)$. Likewise, patients in the intervention group had significantly higher summary scores for all domains on the SF36 questionnaire with the exception of general health and physical functioning. At 12 months, the number of patients adherent to prescribed medications was significantly higher in the intervention versus control group
( $82 \%$ vs. $34 \%, P<0.05$ ). The number of patients adherent to lifestyle adjustment was also significantly better in the intervention group ( $72 \%$ vs. $28 \%, P<0.05)$. Though not statistically significant, there were trends towards reduced hospital admissions (22 vs. 36), albeit an increase in office visits (33 vs. 25), in the intervention group versus control group. This study was unblinded, however, and many outcomes measures, such as adherence, were subjective.

The effect of postdischarge pharmaceutical care plus telemanagement versus usual care was assessed in a randomized, prospective clinical trial in 134 patients admitted for HF in Spain. ${ }^{37}$ Patients were randomized to standard of care or the intervention, which included face-to-face discharge education on disease, medications, and diet in addition to telemanagement. Telemanagement occurred monthly for the first 6 months, followed by every 2 months, for a total of 12 months. Adherence, as measured by pill counts, was higher in 
the intervention group at all time points assessed. This difference was statistically significant at 2 months (88.2\% vs. $60.5 \%$, $P=0.002)$ and 6 months $(91.1 \%$ vs. $69.0 \%, P=0.015)$ but not at 12 months ( $85.0 \%$ vs. $73.9 \%, P=N S$ ). Similarly, the percentage of patients readmitted, the number of readmissions, and the hospital stay days were all lower in the intervention group at all time points but were only statistically significant at 2 and 6 months and not at 12 months. Patients in the intervention group experienced significantly less mortality, which was statistically significant at 12 months (12.9\% vs. 29.7\%, $P=0.017)$.

One of the largest randomized controlled studies to assess pharmacist intervention in HF patients was conducted with 314 low-income HF patients in an ambulatory care clinic in the United States. ${ }^{39}$ Investigators looked at pharmacist intervention, which consisted of a multidisciplinary protocol, including medication reconciliation, assessment of patient knowledge and skills, provision of medications, and verbal and written patient education, compared with usual care. The intervention lasted for 9 months, and patients were followed for 12 months. Medication adherence was assessed using MEMS and refill records. During the 9-month intervention period, medication adherence was $67.9 \%(95 \% \mathrm{CI}=63.8-72.1)$ in the control group and $78.8 \%(95 \% \mathrm{CI}=74.9-82.7)$ in the intervention group, a significant difference of $10.9 \%(95 \% \mathrm{CI}=5.0-16.7)$. However, at 12 months, 3 months after the intervention ceased, the difference in adherence was no longer significant (3.9\%, 95\% $\mathrm{CI}=-2.8-10.7)$. Similarly, there was significantly better medication timing adherence in the intervention group at 9 months (5.9\%, 95\% CI =0.4-11.5), which also dissipated at 12 months (0.3\%, 95\% CI=5.9-6.5). The pharmacy intervention group also experienced significantly fewer hospital admissions and ER visits when compared with the control group (inter-rater reliability [IRR] 0.82, 95\% CI=0.70-0.95).

While most studies demonstrated an improvement in medication adherence, at least early in the intervention, 2 studies did not indicate improvement. ${ }^{43,44}$ In a multicenter study, Tsuyuki et al. (2004) randomized 276 patients discharged with HF to an intervention consisting of patient education, adherence aids, written materials, and medication schedule, conducted by a hospital nurse or pharmacist versus usual care in Canada. ${ }^{43}$ Patients in the intervention group were contacted at 2 weeks and 4 weeks, then monthly thereafter. The control group was contacted monthly only to capture clinical events. After 6 months of follow-up, there was no significant difference in adherence to ACEI between the 2 groups $(86.2 \pm 29 \%$ vs. $83.5 \pm 29 \%)$. There were also no differences in the number of physician visits, ED visits, or readmissions between the 2 groups. There was a significant reduction in the number of cardiovascular-related ED visits (49 vs. $20, P=0.030$ ), the total length of hospital stay (627 days vs. 1,082 days, $P<0.001$ ), and in average length of hospital stay $(6.6 \pm 5.5$ days vs. $11.0 \pm 9.2$ days, $P<0.001$ ).
The effect of a clinical pharmacist discharge service was assessed in 85 patients with HF in a shorter, randomized intervention study in the Netherlands. ${ }^{44}$ Patients were randomized to a pharmacist discharge intervention, including medication reconciliation, communication with providers, and verbal and written patient education versus usual care. At 6 weeks, $68 \%$ of control patients versus $39 \%$ of intervention patients had at least 1 medication discrepancy or error $(R R=0.57,95 \%$ $\mathrm{CI}=0.37-0.88$ ). However, potential medication nonadherence as measured by the Brief Medication Questionnaire was no different between the 2 treatment groups (79.5\% control vs. $78.0 \%$ intervention, $\mathrm{RR}=1.08,95 \% \mathrm{CI}=0.47-2.44)$.

\section{Studies Not Assessing Medication Adherence}

A summary of studies evaluating pharmacist interventions that did not specifically evaluate medication adherence is given in Table 4. ${ }^{45-48}$ The PHARM study assessed the effect of pharmacist involvement in HF management, which included evaluation, therapeutic recommendations, patient education, and telemonitoring for 6 months in the United States. ${ }^{45}$ Patients ( $n=181$ ) with systolic HF were randomized to pharmacist intervention or usual care. Combined all-cause mortality and HF events were significantly lower in the intervention group versus control (4.4\% vs. $17.6 \%$, odds ratio $[\mathrm{OR}]=0.22,95 \%$ $\mathrm{CI}=0.07-0.65, P=0.005)$. This effect was due predominantly to a reduction in hospitalizations and ED visits rather than mortality reduction.

Pharmacist involvement in both inpatient and outpatient care was assessed in 34 patients admitted with HF in a randomized, blinded study in the United States. ${ }^{46}$ Patients were randomized to usual care or care with pharmacy intervention that consisted of corrective action for readmission risk factors, patient education, and a phone call 3-7 days postdischarge. After 12 months, $58.8 \%$ of control and $23.5 \%$ of intervention patients were readmitted $(P<0.05)$. The combined endpoint of death and readmission occurred in $82.3 \%$ of control patients and $29.4 \%$ of intervention patients $(P<0.01)$

Another randomized controlled trial conducted in Australia demonstrated that 1 home-based visit by a pharmacist or nurse after a HF hospitalization could impact outcomes. ${ }^{47}$ Patients ( $n=97$ ) were randomized to usual care or a home-based visit to optimize medications, identify early deterioration, and intensify medical follow-up. The primary endpoint, the incidence of unplanned readmissions plus out-of-hospital deaths within 6 months, was $0.8 \pm 0.9$ versus $1.4 \pm 1.8$ for intervention versus control $(P=0.03)$. This effect was caused primarily by a reduction in readmissions as opposed to death.

Pharmacist involvement for 3 weeks in home care services for HF patients was also assessed in 154 patients in the United States. ${ }^{48}$ Patients were randomized to standardized pharmacy services, including an in-home medication assessment and 2 follow-up visits plus services from the Visiting Nurses Association (VNA) or usual care (VNA services only). After 6 
TABLE 4 Pharmacist Intervention Studies Not Assessing Medication Adherence

\begin{tabular}{|c|c|c|c|c|c|}
\hline $\begin{array}{l}\text { Author, Year, } \\
\text { Country }\end{array}$ & $\begin{array}{l}\text { Design and Number } \\
\text { of Patients }\end{array}$ & Control & Description of Intervention & $\begin{array}{l}\text { Follow-up } \\
\text { Duration }\end{array}$ & Major Outcomes \\
\hline $\begin{array}{l}\text { Gattis, } 199945 \\
\text { United States }\end{array}$ & $\begin{array}{l}\text { Prospective, } \\
\text { randomized, } \\
\text { controlled, } \\
\mathrm{n}=181\end{array}$ & Usual care & $\begin{array}{l}\text { Pharmacist involvement in HF } \\
\text { management (evaluation, therapeutic } \\
\text { recommendations, education) and } \\
\text { telemonitoring }\end{array}$ & 6 months & $\begin{array}{l}\text { Significant reduction in combined all-cause } \\
\text { mortality and } \mathrm{HF} \text { events }(4.4 \% \text { intervention } \\
\text { vs. } 17.6 \% \text { control, OR }=0.22,95 \% \\
\mathrm{CI}=0.07-0.65, P=0.005)\end{array}$ \\
\hline $\begin{array}{l}\text { Rainville, } \\
199946 \\
\text { United States }\end{array}$ & $\begin{array}{l}\text { Prospective, } \\
\text { randomized, } \\
\text { controlled, blinded, } \\
\mathrm{n}=34\end{array}$ & Usual care & $\begin{array}{l}\text { Pharmacist involvement in HF manage- } \\
\text { ment (corrective action for readmission } \\
\text { risk factors, patient education, and a } \\
\text { phone call 3-7 days postdischarge) }\end{array}$ & 12 months & $\begin{array}{l}\text { Significant reduction in readmissions }(58.8 \% \\
\text { control vs. } 23.5 \% \text { intervention, } P<0.05) \text {; sig- } \\
\text { nificant reduction in the combined endpoint } \\
\text { of death and readmission }(82.3 \% \text { control vs. } \\
29.4 \% \text { intervention, } P<0.01)\end{array}$ \\
\hline $\begin{array}{l}\text { Stewart, } \\
1998^{47} \\
\text { Australia }\end{array}$ & $\begin{array}{l}\text { Prospective, } \\
\text { randomized, } \\
\text { controlled, } \\
\mathrm{n}=97\end{array}$ & Usual care & $\begin{array}{l}\text { Single home-based pharmacy visit to } \\
\text { optimize medication, identify early } \\
\text { deterioration, and intensify medical } \\
\text { follow-up }\end{array}$ & 6 months & $\begin{array}{l}\text { Significant reduction in combined primary } \\
\text { endpoint of unplanned readmissions plus } \\
\text { out-of-hospital deaths }(0.8 \pm 0.9 \text { vs. } 1.4 \pm 1.8 \\
\text { for intervention vs. control, respectively, } \\
P=0.03)\end{array}$ \\
\hline $\begin{array}{l}\text { Triller, } \\
2007^{48} \\
\text { United States }\end{array}$ & $\begin{array}{l}\text { Prospective, } \\
\text { randomized, } \\
\text { controlled, } \\
\mathrm{n}=154\end{array}$ & $\begin{array}{l}\text { Usual care } \\
\text { (VNA } \\
\text { services } \\
\text { only) }\end{array}$ & $\begin{array}{l}\text { Pharmacist involvement in home care } \\
\text { for } 3 \text { weeks (medication assessment plus } \\
2 \text { follow-up visits) plus VNA services }\end{array}$ & 6 months & $\begin{array}{l}\text { No significant difference in composite } \\
\text { endpoint of all-cause hospitalization or } \\
\text { death }(61 \% \text { intervention vs. } 62 \% \text { control, } \\
\mathrm{RR}=0.98, P=1.0)\end{array}$ \\
\hline
\end{tabular}

months of follow-up, there were no significant differences in the composite endpoint of all-cause hospitalization or death ( $61 \%$ intervention vs. $62 \%$ control, $R R=0.98, P=1.0$ ). In this study, the pharmacist was not functioning as part of a multidisciplinary team but rather communicating to prescribers through written interventions.

\section{Summary of Pharmacist Interventions}

Most pharmacist intervention studies with a medication adherence outcome demonstrated significant improvements when compared with a control group. ${ }^{36-40}$ Two of the larger and more recent trials indicated that this effect on adherence lacked durability over time, ${ }^{37,39}$ possibly from the Hawthorne or observer effect. Because of the design of these studies, patients were likely aware that they were in the intervention group. Despite the fact that control patients were also periodically contacted to assess for endpoints, intervention patients experienced greater oversight from study personnel and therefore may have increased their compliance merely from participation in a clinical trial. Shorter trials, by design, may have less sensitivity in detecting differences in medication adherence because many patients refill their prescriptions 3 months at a time. Thus, longer trials allowing for more refill opportunities may be more sensitive in detecting changes in medication adherence. Adherence may have declined at the completion of the intervention, and in order to maintain improved adherence, the interventions must continue.

In addition to improvements in adherence, some pharmacy interventions were associated with improvements in exercise tolerance, forced vital capacity, quality of life, and decreased hospitalizations. In a meta-analysis of 12 randomized controlled trials assessing the impact of pharmacist care activities in HF patients, pharmacist care was associated with a significant reduction in all-cause hospitalizations ( $O R=0.71,95 \%$ $\mathrm{CI}=0.54-0.94, P=0.02)$ and a nonsignificant reduction in mortality (OR $=0.84,95 \% \mathrm{CI}=0.61-1.15) .{ }^{17}$ Interestingly, interventions where the pharmacist participated as part of a multidisciplinary team (collaborative care) led to greater reductions in HF hospitalizations when compared with pharmacist-directed care $(\mathrm{OR}=0.42,95 \% \mathrm{CI}=0.24-0.74, P=0.002$ vs. $\mathrm{OR}=0.89$, $95 \% \mathrm{CI}=0.68-1.17, P=0.41$, respectively).

Another meta-analysis assessing comprehensive HF discharge planning and postdischarge support studies also demonstrated that most types of postdischarge support, including single home visits, home visits plus frequent telephone contact, and extended home care services, significantly reduced hospital readmissions $(\mathrm{RR}=0.75,95 \% \mathrm{CI}=0.64-0.88, \mathrm{P}<0.001){ }^{49}$ However, increased clinic follow-up and/or frequent telephone contact did not reduce readmissions. The meta-analysis also found trends towards reduced mortality ( $\mathrm{RR}=0.87,95 \%$ $\mathrm{CI}=0.73-1.03, P$ for heterogeneity=0.06), though most trials were not powered to assess this secondary outcome. Although not statistically significant, there were consistent reductions in length of stay in the intervention groups as well. Though not pharmacist specific, this analysis suggests that face-to-face interventions performed at discharge or shortly thereafter, as opposed to telephone contact, may be more effective at improving outcomes. ${ }^{37}$ These data, in addition to evidence supporting a dissipation of adherence once the intervention is complete, support the notion that pharmacist interventions should be part of a multidisciplinary system of care initiated at discharge that involves personal contact and is continued indefinitely in order to sustain these benefits. 


\section{Tools to Predict Nonadherence in Heart Failure}

It would be helpful if tools were available to assist pharmacists with identifying patients at risk of medication nonadherence in clinical practice, so that interventions could be implemented to prevent or decrease nonadherence. Research shows that clinicians are poor at predicting medication adherence without specific aids, often overestimating medication adherence. ${ }^{50}$ Although many adherence screening tools have been developed to attempt to predict medication nonadherence, few have been validated extensively, and still fewer have been specifically evaluated in a HF population. However, there are some aids or tools that may be of benefit in HF patients.

Two HF-specific tools have been developed, the Heart Failure Compliance Questionnaire and the Medication Adherence Scale. ${ }^{7,51-53}$ The Heart Failure Compliance Questionnaire was developed in 2001 and has been used to screen for medication and lifestyle nonadherence in several HF studies. ${ }^{51-53}$ When compared with the objectively measured MEMS, this tool found $100 \%$ of patients reported adherence, while the MEMS found only $76 \%$ adherent, suggesting poor concordance. Therefore, despite its popularity, the tool has undergone limited validation and successful correlation with objective measures of nonadherence and with adverse clinical outcomes. ${ }^{51-53}$ Because of this lack of validation, the tool cannot be recommended for use in clinical practice until further validation work is conducted. The Medication Adherence Scale is an 18-item scale that has undergone initial validation against MEMS in a population of 100 advanced chronic HF patients (66\% New York Heart Association Class III/IV). Small but statistically significant correlations were found between MEMS and the Attitude subscale $(r=0.30, P<0.05)$ and the Barrier subscale $(r=-0.25$ to -0.31 , $P<0.05)$. The scale's small magnitude of correlations with MEMS is not impressive, and the 18-question length of the scale may limit its practicality in clinical practice.

The Morisky Medication Adherence Scale (MMAS) is the best validated short questionnaire that has been tested in patients with hypertension or diabetes and in those taking chronic cardiovascular medications, such as lipid-lowering agents and ACEIs. ${ }^{54-56}$ The questionnaire was initially validated in a hypertensive population and found to be correlated with blood pressure control at 2 and 5 years. It has high sensitivity of 0.81 and low specificity of 0.44 , meaning that if a patient is found to have high risk for nonadherence with the MMAS, that

\section{TABLE 5 Morisky Medication Adherence Scale}

1. Do you ever forget to take your medicine?

2. Are you careless at times about taking your medicine?

3. When you feel better do you sometimes stop taking your medicine?

4. Sometimes if you feel worse when you take the medicine, do you stop taking it?

a Morisky et al. (1986). ${ }^{54}$ Scoring: yes $=0$, no $=1$, range 0-4 (high risk $=0$, medium risk $=1-2$, low risk=3-4).

result is likely true..$^{54}$ However, the tool still may miss some patients who are nonadherent. The 4-item yes/no questions about past medication use make it a quick and simple tool to use in practice (Table 5) ${ }^{54}$ While the 4 -item version is the best validated and tested scale, an expanded 8-item scale has recently been developed and undergone limited validity testing in a hypertensive population. ${ }^{57}$ This newly expanded tool may be a future option after it is tested in more diverse populations, including those with HF.

The Merck Adherence Estimator is a newer screening tool developed by Colleen McHorney, a former senior director of outcomes research at Merck. It has been tested in patients with chronic asymptomatic diseases, such as hypertension and hyperlipidemia. ${ }^{58,59}$ It has not been specifically tested in patients who have HF, and since HF is a symptomatic condition, whether the tool would perform as well in this population is unclear. It asks 3 simple questions with a 6-point response scale. A numeric score value is assigned to the potential 6 responses to each of the 3 patient questions. Patients can easily be placed into 3 categories of low to high risk for adherence based on their total score (Table 6). ${ }^{58,59}$ When compared with patient self-report, sensitivity was high at $88 \%$, meaning that $88 \%$ of nonadherers were accurately classified as medium or high risk of nonadherence by the Adherence Estimator. ${ }^{58}$ When compared with pharmacy claims data, the sensitivity was $61.2 \%$, specificity $49.0 \%$, and positive predictive value $68.4 \%$. These numbers mean that $61.2 \%$ of those who were nonadherent with pharmacy claims data were accurately classified as medium or high risk by the Adherence Estimator; $49.0 \%$ of those who were adherent with claims were accurately classified as low risk on the Adherence Estimator; and among those who were medium or high risk with the Estimator, 68.4\%

\section{TABLE 6 Merck Adherence Estimator ${ }^{a}$}

\begin{tabular}{|c|c|c|c|c|c|c|}
\hline & $\begin{array}{c}\text { Agree } \\
\text { Completely }\end{array}$ & Agree Mostly & $\begin{array}{c}\text { Agree } \\
\text { Somewhat }\end{array}$ & $\begin{array}{l}\text { Disagree } \\
\text { Somewhat }\end{array}$ & $\begin{array}{c}\text { Disagree } \\
\text { Mostly }\end{array}$ & $\begin{array}{l}\text { Disagree } \\
\text { Completely }\end{array}$ \\
\hline I am convinced of the importance of my prescription medication. & 0 & 0 & 7 & 7 & 20 & 20 \\
\hline $\begin{array}{l}\text { I worry that my prescription medication will do more harm than } \\
\text { good to me. }\end{array}$ & 14 & 14 & 4 & 4 & 0 & 0 \\
\hline $\begin{array}{l}\text { I feel financially burdened by my out-of-pocket expenses for my } \\
\text { prescription medication. }\end{array}$ & 2 & 2 & 0 & 0 & 0 & 0 \\
\hline
\end{tabular}

a McHorney (2009) 58 and McHorney et al. (2009). ${ }^{59}$ Total scoring: $0=$ low risk, $1-7=$ medium risk, $8+=$ high risk 
became nonadherent according to pharmacy claims data. ${ }^{59}$ The tool is available for patients to self-administer at http://www. merckengage.com/rxforhealth/adherence-estimator.aspx or for provider or patient administration at www.adherenceestimator. com. It appears to be quite simple to use in practice as long as a computer is available to use these websites. Use of the tool in other settings and offline requires more effort to add the total scores and also needs permission from Merck \& Co., Inc. both of which somewhat limit its practicality.

The Heart and Soul Study evaluated a simple 1-question survey in patients with stable coronary artery disease (CAD), rather than HF. ${ }^{60}$ It asks: "In the past month, how often did you take your medications as the doctor prescribed?" In the stable CAD population, nonadherence (patients reported taking their medications $\leq 75 \%$ of the time) was associated with a 2-fold higher rate of subsequent cardiovascular events. ${ }^{59}$ Unfortunately, the tool has not been tested specifically in patients who have HF. Its simplicity in having only 1 question is attractive, but its sensitivity to detect medication adherence has received limited testing, and it cannot be recommended at this time in HF patients.

Some validation testing has been done on 4 survey tools for medication nonadherence, but because of their length, they are not especially applicable to everyday clinical practice. The Brief Medication Questionnaire is a 30-item survey that has been tested in the general population with diabetes, depression, and other chronic diseases. ${ }^{61}$ The ASK-20 is a 20 -item survey and is one of the few tools that has been assessed in patients with $\mathrm{HF}$, as well as in patients with diabetes and depression. ${ }^{62}$ The Self-Efficacy for Appropriate Medication use Scale (SEAMS) is a 13-item tool that was evaluated in low-literacy patients with coronary heart disease and other comorbid conditions, with good internal consistency. ${ }^{63}$ The Hill-Bone Compliance to High Blood Pressure Therapy Scale is a 14-item scale, focused specifically on hypertension. ${ }^{64}$ All 4 of these tools are not especially practical for routine clinical use because of their length, and only the ASK-20 was specifically assessed in HF patients. ${ }^{61-64}$

While the development of adherence screening tools has been an active area of clinical research in recent years, further work is needed to create a tool that will be applicable to a HF population in clinical practice. At the present time, the MMAS and the Merck Adherence Estimator may be potentially useful for pharmacists or other health care providers in identifying nonadherence in HF patients..$^{54,58}$ However, more validation research of these tools is needed in HF patients.

\section{Discussion}

This review provides practitioners with predictors of medication adherence and nonadherence in HF patients. Furthermore it provides a comprehensive analysis of studies evaluating pharmacist involvement in the treatment of $\mathrm{HF}$ and a critical analysis of practical tools for identifying nonadherence in HF patients.

Factors affecting medication adherence are complex and multifaceted. Nonadherence to HF medication has also been associated with an increase in cardiac-related events, including ED visits and hospitalizations, an increase in health care costs, and a reduction in quality of life. It is important for health care providers to recognize predictors of HF medication adherence. However, more research is needed to further examine these dimensions where data are lacking, especially in the areas of socioeconomic and health care systems.

Pharmacists are well suited to optimize drug therapy regimens, identify barriers to medication adherence and develop ways to address these, and educate patients and the health care team about medication-related topics. Multidisciplinary interventions, including pharmacists with both inpatient and outpatient medical teams, can improve medication adherence and reduce hospital admissions, with the potential to improve mortality. However, the literature suggests that this improvement in adherence may lack durability over time. Therefore, pharmacist interventions should be part of a multidisciplinary system of care initiated at discharge that involves personal contact and is continued indefinitely in order to sustain benefit. There is opportunity for pharmacist involvement in many systems of care, including inpatient, ambulatory, and community settings.

Limited data have been published validating simplified survey tools to proactively identify patients at risk for nonadherence to their HF medications. The MMAS and the Merck Adherence Estimator have only been validated to correlate with medication nonadherence in non-HF populations, but their brevity and simplicity make them attractive tools to incorporate into clinical practice and validate in HF patients.

\section{Limitations}

This review was limited to articles published in English. Most predictor and pharmacist intervention studies took place in Western developed countries; therefore, the results may be less generalizable to patients in other countries. Furthermore, because pharmacotherapy for HF only has an established mortality benefit for patients with reduced ejection fraction etiology, most studies only included patients with HF with reduced ejection fraction. Therefore, providers should use caution when extrapolating these findings to patients with HF with preserved ejection fraction.

\section{Conclusions}

Hospital readmissions due to heart failure are common, and nonadherence to medications and/or lifestyle changes contributes to hospitalization. Clinicians should be cognizant of factors that may affect medication adherence in heart failure patients and be aware of instruments available to predict the risk for medication nonadherence. Pharmacist interventions should be part of a multidisciplinary system of care initiated at discharge that involves personal contact and are continued indefinitely in order to sustain these benefits. 


\section{Authors}

ESTELLA M. DAVIS, PharmD, BCPS, is Associate Professor of Pharmacy Practice, and KATHLEEN A. PACKARD, PharmD, BCPS (AQ Cardiology), is Associate Professor of Pharmacy Practice, Department of Pharmacy Practice, Creighton University School of Pharmacy and Health Professions, Omaha, Nebraska. CYNTHIA A. JACKEVICIUS, BScPhm, PharmD, MSc, FCSHP, BCPS (AQ Cardiology), FAHA, is Professor of Pharmacy Practice and Director, Residency \& Fellowship Training, Department of Pharmacy Practice $\mathcal{E}$ Administration, Western University of Health Sciences, College of Pharmacy, Pomona, California.

AUTHOR CORRESPONDENCE: Estella M. Davis, PharmD, BCPS, Creighton University School of Pharmacy and Health Professions, 2500 California Plaza, Omaha, NE 68178. Tel.: 402.398.5646; Fax: 402.398.5928; E-mail: edavis@creighton.edu.

\section{DISCLOSURES}

The authors attest that they have no financial interests, arrangements, or other conflicts of interest to disclose. All authors contributed equally to study design and writing the manuscript, which was revised primarily by Davis and Packard, with assistance from Jackevicius.

\section{REFERENCES}

1. Go AS, Mozaffarian D, Roger VL, et al. Heart disease and stroke statistics-2013 update: a report from the American Heart Association. Circulation. 2013;127(1):e6-e245.

2. Centers for Medicare and Medicaid Services. Readmissions reduction program. Updated April 30, 2014. Available at: http://www.cms.gov/Medicare/ Medicare-Fee-for-Service-Payment/AcuteInpatientPPS/ReadmissionsReduction-Program.html. Accessed May 17, 2014.

3. Krumholz HM, Parent EM, Tu N, et al. Readmission after hospitalization for congestive heart failure among Medicare beneficiaries. Arch Intern Med. 1997;157(1):99-104.

4. Curtis LH, Greiner MA, Hammill BG, et al. Early and long-term outcomes of heart failure in elderly persons, 2001-2005. Arch Intern Med. 2008; 168(22):2481-88

5. Annema C, Luttik ML, Jaarsma T. Reasons for readmission in heart failure: perspectives of patients, caregivers, cardiologists, and heart failure nurses. Heart Lung. 2009;38(5):427-34.

6. Ambardekar AV, Fonarow GC, Hernandez AF, Pan W, Yancy CW, Krantz MJ. Characteristics and in-hospital outcomes for nonadherent patients with heart failure: findings from the Get With The Guidelines-Heart Failure (GWTG-HF). Am Heart J. 2009;158(4):644-52.

7. Wu JR, Moser DK, Lennie TA, Burkhart PV. Medication adherence in patients who have heart failure: a review of the literature. Nurs Clin North Am. 2008;43(1):133-53.

8. Hope CJ, Wu J, Tu W, Young J, Murray MD. Association of medication adherence, knowledge, and skills with emergency department visits by adults 50 years or older with congestive heart failure. Am J Health Syst Pharm. 2004;61(19):2043-49.
9. Sokol MC, McGuigan KA, Verbrugge RR, Epstein RS. Impact of medication adherence on hospitalization risk and healthcare cost. Med Care. 2005;43(6):521-30.

10. George J, Shalansky SJ. Predictors of refill non-adherence in patients with heart failure. Br J Clin Pharmacol. 2007;63(4):488-93.

11. Sun SX, Ye X, Lee KY, Dupclay L, Plauschinat C. Retrospective claims database analysis to determine relationship between renin-angiotensin system agents, rehospitalization, and health care costs in patients with heart failure or myocardial infarction. Clin Ther. 2008;30(Pt. 2):2217-27.

12. Mockler M, O'Loughlin C, Murphy N, et al. Causes and consequences of nonpersistence with heart failure medication. Am J Cardiol. 2009;103(6):834-38.

13. Murray MD, Tu W, Wu J, Morrow D, Smith F, Brater DC. Factors associated with exacerbation of heart failure include treatment adherence and health literacy skills. Clin Pharmacol Ther. 2009;85(6):651-58.

14. Lopert R, Shoemaker JS, Davidoff A, et al. Medication adherence and Medicare expenditure among beneficiaries with heart failure. Am J Manag Care. 2012;18(9):556-63.

15. Granger BB, Swedberg K, Ekman I, et al. Adherence to candesar$\tan$ and placebo and outcomes in chronic heart failure in the CHARM programme: double-blind, randomised, controlled clinical trial. Lancet. 2005;366(9502):2005-11.

16. Milfred-LaForest SK, Chow SL, DiDomenico RJ, et al. Clinical pharmacy services in heart failure: an opinion paper from the Heart Failure Society of America and American College of Clinical Pharmacy Cardiology Practice and Research Network. Pharmacotherapy. 2013;33(5):529-48.

17. Koshman SL, Charrois TL, Simpson SH, McAlister FA, Tsuyuki RT. Pharmacist care of patients with heart failure: a systematic review of randomized trials. Arch Intern Med. 2008;168(7):687-94.

18. Sabaté E. Adherence to Long-Term Therapies: Evidence for Action. Geneva: World Health Organization; 2003.

19. Osterberg L, Blaschke T. Adherence to medication. N Engl J Med. 2005;353(5):487-97.

20. Leventhal MJ, Riegel B, Carlson B, De Geest S. Negotiating compliance in heart failure: remaining issues and questions. Eur J Cardiovasc Nurs 2005;4(4):298-307.

21. Calvin JE, Shanbhag S, Avery E, Kane J, Richardson D, Powell L. Adherence to evidence-based guidelines for heart failure in physicians and their patients: lessons from the Heart Failure Adherence Retention Trial (HART). Congest Heart Fail. 2012;18(2):73-78.

22. Granger BB, Ekman I, Granger CB, et al. Adherence to medication according to sex and age in the CHARM programme. Eur J Heart Fail. 2009;11(11):1092-98

23. Setoguchi S, Choudhry NK, Levin R, Shrank WH, Winkelmayer WC. Temporal trends in adherence to cardiovascular medications in elderly patients after hospitalization for heart failure. Clin Pharmacol Ther. 2010;88(4):548-54.

24. Riegel B, Lee CS, Ratcliffe SJ, et al. Predictors of objectively measured medication nonadherence in adults with heart failure. Circ Heart Fail. 2012;5(4):430-36.

25. Riegel B, Moelter ST, Ratcliffe SJ, et al. Excessive daytime sleepiness is associated with poor medication adherence in adults with heart failure. J Card Fail. 2011;17(4):340-48. 
26. Chui MA, Deer M, Bennett SJ, et al. Association between adherence to diuretic therapy and health care utilization in patients with heart failure. Pharmacotherapy. 2003;23(3):326-32.

27. Gislason GH, Rasmussen JN, Abildstrom SZ, et al. Persistent use of evidence-based pharmacotherapy in heart failure is associated with improved outcomes. Circulation. 2007;116(7):737-44.

28. Hansen RA, Dusetzina SB, Song L, Gaynes BN, Tu W, Murray MD. Depression affects adherence measurement but not the effectiveness of an adherence intervention in heart failure patients. J Am Pharm Assoc (2003). 2009;49(6):760-68

29. Lamb DA, Eurich DT, McAlister FA, et al. Changes in adherence to evidence-based medications in the first year after initial hospitalization for heart failure: observational cohort study from 1994 to 2003. Circ Cardiovasc Qual Outcomes. 2009;2(3):228-35.

30. Noureldin M, Plake KS, Morrow DG, Tu W, Wu J, Murray MD. Effect of health literacy on drug adherence in patients with heart failure. Pharmacotherapy. 2012;32(9):819-26.

31. Wu JR, Lennie TA, Chung ML, et al. Medication adherence mediates the relationship between marital status and cardiac event-free survival in patients with heart failure. Heart Lung. 2012;41(2):107-14.

32. Cole JA, Norman H, Weatherby LB, Walker AM. Drug copayment and adherence in chronic heart failure: effect on cost and outcomes. Pharmacotherapy. 2006;26(8):1157-64.

33. Wu JR, Frazier SK, Rayens MK, Lennie TA, Chung ML, Moser DK. Medication adherence, social support, and event-free survival in patients with heart failure. Health Psychol. 2013;32(6):637-46.

34. Wu JR, Lennie TA, De Jong MJ, et al. Medication adherence is a mediator of the relationship between ethnicity and event-free survival in patients with heart failure. J Card Fail. 2010;16(2):142-49.

35. Canty-Mitchell J, Zimet GD. Psychometric properties of the Multidimensional Scale of Perceived Social Support in urban adolescents. Am J Community Psychol. 2000;28(3):391-400.

36. Sadik A, Yousif M, McElnay JC. Pharmaceutical care of patients with heart failure. Br J Clin Pharmacol. 2005;60(2):183-93.

37. López Cabezas C, Falces Salvador C, Cubí Quadrada D, et al. Randomized clinical trial of a postdischarge pharmaceutical care program vs. regular follow-up in patients with heart failure. Farm Hosp. 2006;30(6):328-42.

38. Bouvy ML, Heerdink ER, Urquhart J, Grobbee DE, Hoes AW, Leufkens HG. Effect of a pharmacist-led intervention on diuretic compliance in heart failure patients: a randomized controlled study. J Card Fail. 2003;9(5):404-11.

39. Murray MD, Young J, Hoke S, et al. Pharmacist intervention to improve medication adherence in heart failure: a randomized trial. Ann Intern Med. 2007;146(10):714-25

40. Goodyer LI, Miskelly F, Milligan P. Does encouraging good compliance improve patients' clinical condition in heart failure? Br J Clin Pract. 1995;49(4):173-76.

41. Varma S, McElnay JC, Hughes CM, Pasmore AP, Varma M.

Pharmaceutical care of patients with congestive heart failure: interventions and outcomes. Pharmacotherapy. 1999;19(7):860-69.
42. Gwadry-Sridhar FH, Arnold JM, Zhang Y, Brown JE, Marchiori G, Guyatt G. Pilot study to determine the impact of a multidisciplinary educational intervention in patients hospitalized with heart failure. Am Heart J. 2005;150(4):982.

43. Tsuyuki RT, Fradette M, Johnson JA, et al. A multicenter disease management program for hospitalized patients with heart failure. J Card Fail. 2004;10(6):473-80.

44. Eggink RN, Lenderink AW, Widdershoven JW, van den Bemt PM. The effect of a clinical pharmacist discharge service on medication discrepancies in patients with heart failure. Pharm World Sci. 2010;32(6):759-66.

45. Gattis WA, Hasselblad V, Whellan DJ, O'Connor CM. Reduction in heart failure events by the addition of a clinical pharmacist to the heart failure management team: results of the Pharmacist in Heart Failure Assessment Recommendation and Monitoring (PHARM) Study. Arch Intern Med. 1999;159(16):1939-45.

46. Rainville EC. Impact of pharmacist interventions on hospital readmissions for heart failure. Am J Health Syst Pharm. 1999;56(13):1339-42.

47. Stewart S, Pearson S, Horowitz JD. Effects of a home-based intervention among patients with congestive heart failure discharged from acute hospital care. Arch Intern Med. 1998;158(10):1067-72.

48. Triller DM, Hamilton RA. Effect of pharmaceutical care services on outcomes for home care patients with heart failure. Am J Health Syst Pharm. 2007;64(21):2244-49

49. Phillips CO, Wright SM, Kern DE, Singa RM, Shepperd S, Rubin HR. Comprehensive discharge planning with postdischarge support for older patients with congestive heart failure: a meta-analysis. JAMA. 2004;291(11):1358-67.

50. Trindade AJ, Ehrlich A, Kornbluth A, Ullman TA. Are your patients taking their medicine? Validation of a new adherence scale in patients with inflammatory bowel disease and comparison with physician perception of adherence. Inflamm Bowel Dis. 2011;17(2):599-604.

51. Evangelista LS, Berg J, Dracup K. Relationship between psychosocial variables and compliance in patients with heart failure. Heart Lung. 2001;30(4):294-301.

52. van der Wal MH, Jaarsma T, Moser DK, Veeger NJ, van Gilst WH, van Veldhuisen DJ. Compliance in heart failure patients: the importance of knowledge and beliefs. Eur Heart J. 2006;27(4):434-40.

53. Nieuwenhuis MM, Jaarsma T, van Veldhuisen DJ, van der Wal MH. Selfreported versus "true" adherence in heart failure patients: a study using the Medication Event Monitoring System. Neth Heart J. 2012;20(7-8):313-19.

54. Morisky DE, Green LW, Levine DM. Concurrent and predictive validity of a self-reported measure of medication adherence. Med Care. 1986;24(1):67-74.

55. Shalansky SJ, Levy AR, Ignaszewski AP. Self-reported Morisky score for identifying nonadherence with cardiovascular medications. Ann Pharmacother. 2004;38(9):1363-68.

56. Krapek K, King K, Warren SS, et al. Medication adherence and associated hemoglobin Alc in type 2 diabetes. Ann Pharmacother. 2004;38(9):1357-62.

57. Morisky DE, Ang A, Krousel-Wood M, Ward HJ. Predictive validity of a medication adherence measure in an outpatient setting. J Clin Hypertens (Greenwich). 2008;10(5):348-54. 
58. McHorney CA. The Adherence Estimator: a brief, proximal screener for patient propensity to adhere to prescription medications for chronic disease. Curr Med Res Opin. 2009;25(1):215-38.

59. McHorney CA, Victor Spain C, Alexander CM, Simmons J. Validity of the adherence estimator in the prediction of 9-month persistence with medications prescribed for chronic diseases: a prospective analysis of data from pharmacy claims. Clin Ther. 2009;31(11):2584-607.

60. Gehi AK, Ali S, Na B, Whooley MA. Self-reported medication adherence and cardiovascular events in patients with stable coronary heart disease: the Heart and Soul Study. Arch Intern Med. 2007;167(16):1798-803.
61. Svarstad BL, Chewing BA, Sleath BL, Claesson C. The Brief Medication Questionnaire: a tool for screening patient adherence and barriers to adherence. Patient Educ Couns. 1999;37(2);113-24.

62. Hahn SR, Park J, Skinner EP, et al. Development of the ASK-20 adherence barrier survey. Curr Med Res Opin. 2008;24(7):2127-38.

63. Risser J, Jacobson TA, Kripalani S. Development and psychometric evaluation of the Self-Efficacy for Appropriate Medication Use Scale (SEAMS) in low-literacy patients with chronic disease. J Nurs Meas. 2007;15(3):203-19.

64. Kim MT, Hill MN, Bone LR, Levine DM. Development and testing of the Hill-Bone Compliance to High Blood Pressure Therapy Scale. Prog Cardiovasc Nurs. 2000;15(3):90-96. 